\title{
The management of Pevensey shingle barrier
}

\author{
James Sutherland $^{1}$ and Ian Thomas $^{2}$ \\ ${ }^{1}$ HR Wallingford, Howbery Park, Wallingford, Oxfordshire, OX10 8BA, UK. Email: i.sutherland@hrwallingford.com (corresponding author) \\ 2 Pevensey Coastal Defence, Coast Road, Pevensey Bay, East Sussex, BN24 6ND, UK. Email pcdl@pevensey-bay.co.uk
}

Published in the Journal of Ocean and Coastal Management 54 (2011), pp. 919-929

\section{Abstract}

The shingle (gravel) barrier beach at Pevensey Bay (East Sussex, UK) protects rare habitat, properties, trunk roads and other assets from flooding and erosion. The beach is managed in an adaptive manner by a private consortium, based on a 25 year contract. The practices developed at Pevensey are shown to fit into the frame of reference approach, adapted for the English policy and management framework. The barrier beach is managed to retain a favourable sediment status, although the concept has no official recognition, thereby ensuring that the barrier is sufficiently resilient to maintain its functions between interventions. The concept of favourable sediment status is considered a potentially useful way of summarising the status of the beach at Pevensey as it combines management objectives and processes (through coastal state indicators) with the availability of supply. The concept of the coastal sediment cell is important, but not sufficient, for identifying policy units at Pevensey as smaller-scale processes are also important. Two offshore dredging areas constitute the strategic sediment reservoir for Pevensey, although the term 'strategic sediment reservoir' has no official recognition and there is no long-term guarantee of supply.

\section{Introduction}

Shingle is an imprecise description of a mix of sand (with diameter 0.06 to $2 \mathrm{~mm}$ ), gravel ( $2 \mathrm{~mm}$ to $60 \mathrm{~mm}$ ) and cobbles (greater than $60 \mathrm{~mm}$ ). Shingle barrier beaches can be overtopped by large waves, may leak or rollback landward, and ultimately may breach, so represent a flood risk (Stripling et al, 2008). Shingle beaches (also known as gravel beaches or coarse clastic beaches) are commonly found in areas where, in previous Ice Ages, glaciers have produced and transported such sediments to the coastline.

This paper looks at how the flood and coastal erosion risks associated with the shingle barrier beach at Pevensey Bay (Sussex, UK - see Figure 1) are managed and how the management process can be represented systematically using the frame of reference approach (as discussed in Section 3 of this paper) which requires clear objectives at the strategic and tactical levels and includes a decision making procedure at the operational level. The lessons from this case study may be relevant for other locations where a shingle or gravel nourishment is being considered, even if the existing beach is of sand.

This work was undertaken as part of the project Concepts and Science for Coastal Erosion Management (http://www.conscience-eu.net/) which developed and tested concepts, guidelines and tools for the sustainable management of coastal erosion (Marchand et al., 2011). In particular, the applicability of the concepts of coastal resilience, strategic sediment reservoir, favourable sediment status and coastal sediment 
cell - as proposed by the Eurosion project (European Commission, 2004) for the management of coastal erosion - has been assessed for the Pevensey shingle barrier beach.

The $9 \mathrm{~km}$ long shingle barrier beach at Pevensey Bay is the primary flood and coastal erosion risk management asset (defence) along the frontage between Eastbourne and Cooden in East Sussex, on the English Channel coast of southern England (see Figure 2). Many properties have been constructed on the crest of this shingle barrier beach. Immediately inland there is the Pevensey Levels, an area of about 50 $\mathrm{km}^{2}$, which could be flooded at high spring tide if the shingle barrier beach were to become breached. The Pevensey Levels themselves are an area of low-lying marshland prized for its high conservation and agricultural value. The area at risk contains over 10,000 properties, plus caravan parks, trunk roads and a mainline rail link. Temporary flooding events occurred at Pevensey in 1926, 1935, 1965 and 1999.

The main coastal problem in managing the shingle barrier beach at Pevensey is that the nett loss of sediment from the barrier beach and the rise in sea level both reduce the volume of sediment above sea level, thereby increasing the risk of damage caused by flooding as well as the direct loss of land. The natural response to the loss of sediment and increasing sea levels would be for the shingle barrier to rollback and, in the long term, either re-align to form a swash-aligned bay beach or to breach. A large breach could re-form a tidal inlet. The beach is managed to prevent this happening (Hardacre and Chester, 2001).

The main risk at Pevensey is damage caused by flooding, rather than the loss of assets to erosion, so managing the flood risk is the responsibility of the Environment Agency (2011). However, the Environment Agency has contracted out management of the barrier beach to the Pevensey Coastal Defence consortium for a period of 25 years to June 2025 as a pathfinder sea defence project in the form of a Public Private Partnership, formerly known as the Private Finance Initiative (Hardacre and Chester, 2001).

\section{Coastal processes}

\subsection{Description of the coastline}

The western limit of the shoreline considered here is Beachy Head, the moderately resistant, 150m high, chalk cliff that forms the western end of the sediment sub-cell 4c for beach sand (Motyka and Brampton, 1993) and the western limit of the South Foreland to Beachy Head Shoreline Management Plan (Halcrow, 2006) that includes Pevensey (Figure 1). This is not a completely closed boundary for sediment and the beaches of Eastbourne (Figure 2) have traditionally relied on a supply of gravel from the west, although this has been much reduced by the construction of man-made structures. Sediment is also provided by the erosion of the shore platform and cliffs around Beachy Head, although these contain only a small percentage of potential beach material.

The height of the chalk cliff decreases on going northeast from Beachy Head and the cliff top reaches sea level on the north-eastern side of Eastbourne. The toe of the cliff at Eastbourne is protected by sea walls, while wooden groynes and shingle nourishment are used to maintain a narrow beach. The last nourishment of the beach at Eastbourne was in 1998.

A cuspate foreland known as the Crumbles is believed to have developed through the onshore migration of a gravel bar between 1100 AD and 1600 AD (Defra, 2002). Longshore drift then moved gravel northeastwards along the coastline, causing the Crumbles' shoreline to retreat. It is believed this area no longer receives a supply of gravel from offshore sources (Defra, 2002). 
In 1993 Sovereign Harbour marina was excavated out of the Crumbles and rubble mound breakwaters were constructed at the north and south of the marina entrance. Longshore drift causes gravel to accumulate against the southern side of the harbour and erosion to occur on the northern side (Figure 3), which is managed by periodic beach nourishment and the bypassing of gravel by lorry round the harbour from south to north. Beach recharge (nourishment) is accomplished by rainbowing shingle from offshore dredging sites onto the upper foreshore (Figure 4). For the last 2 years this has been left in situ, although previously some was bulldozed onto the front crest of the barrier beach.

The barrier beach extends around Pevensey Bay and protects the Pevensey Levels, more than $50 \mathrm{~km}^{2}$ of low-lying land, from flooding. Pevensey Levels used to be a tidal inlet before the longshore drift of shingle from the Crumbles enclosed it. The Pevensey Levels are a Ramsar site with low-lying coastal wetlands that would be vulnerable to saline flooding. They are also a National Nature Reserve and a Site of Special Scientific Interest, which extends onto the beach at Normans Bay. Both are national designations. The beach also contains two Sites of Nature Conservation Interest where there is vegetated shingle.

This shoreline becomes increasingly exposed to wave attack towards the east as the shelter from Beachy Head and Sovereign Harbour diminishes. About 150 wooden groynes were constructed along this frontage during the $20^{\text {th }}$ century (Halcrow, 2006), most of which are in a poor state of repair (Figure 5) and are gradually being removed as they fail in a process that started in 2000. A few key groynes have been replaced or repaired (Figure 6) and Pevensey Coastal Defence expect to retain no more than ten.

A considerable number of properties have been constructed on the crest of the barrier beach and some are susceptible to damage. For example, the most recent significant storm, on $24^{\text {th }}$ October 1999 , damaged more than 50 of them. The eastern limit of the shoreline considered here is Cooden where the hinterland rises too high to flood, so the main risk changes and the management of this frontage is considered separately (Halcrow, 2006).

\subsection{Waves and water levels}

Wave data from the Pevensey Bay wave buoy (see Figure 2) have been collected for the period from 2003 to 2008. Marginal extreme significant wave heights are shown in Table 1, with marginal extreme water levels (JBA, 2004). A typical barrier crest elevation is between 6.0mOD and 6.5mOD, where OD is Ordnance Datum, which corresponds approximately to mean water level at Newlyn.

The highest waves arrive predominantly from the south-south-west, having been generated in the long fetches to the southwest and refracted around Beachy Head. A smaller proportion of waves arrive from the east, as shown in Figure 7. The direction of nett wave driven longshore sediment transport is from southwest to northeast. Transport of the shingle is mainly by wave action near the shoreline due to the large particle size, low tidal velocities and steep beach faces. Waves and water level are therefore the crucial drivels of flood and coastal erosion risk.

\subsection{Sediment budget}

Halcrow (2006) analysed the 30 years of Annual Beach Monitoring Survey data that was available, which indicated a nett loss of $22,000 \mathrm{~m}^{3}$ of shingle per year from the Crumbles to Cooden frontage. Since July 2004 , when the effects of a major capital recharge in 2002 had diminished, an annual average of $25,000 \mathrm{~m}^{3}$ of sediment has been added to the barrier beach to maintain its volume. About $20 \%$ of the nourishment 
material consists of fines and is likely to disperse, which indicates losses of around $20,000 \mathrm{~m}^{3}$ per year of shingle, consistent with the earlier calculation.

\section{Beach Management}

The barrier beach is managed in an adaptive manner developed by Pevensey Coastal Defence, where management activities respond to changes in risk, as determined from regular monitoring. The adaptive management approach is in line with principles set out in 'The national flood and coastal erosion risk management strategy for England' (Environment Agency 2011) and is considered appropriate when ongoing responsibility can be assigned to an operating authority to track the change in risk and intervene as necessary (Defra, 2009). It is described here in terms of the frame of reference approach (van Koningsveld and Mulder, 2004, Marchand et al., 2011) which provides a systematic framework for the development and implementation of a policy for coastal management. The application of the frame of reference requires a strategic objective to be set and a tactical objective chosen as the local management policy (Section 3.1), a four-stage decision making process to decide how to implement the tactical objective (Section 3.2) and a review against the objectives (Section 3.3) as illustrated in Figure 8. Differences from the generic frame of reference (van Koningsveld and Mulder, 2004, Marchand et al., 2011) are discussed in Section 3.4.

\subsection{Strategic and tactical objectives}

Flood and coastal erosion risk management legislation is largely permissive in England which means that there is no right to any particular standard of protection from floods or erosion (Defra, 2009). Flood and coastal erosion risk management policy is set by the government, led by the Department for the Environment, Food and Rural Affairs (Defra). The Flood and Water Management Act (HMSO, 2010) gave the Environment Agency (an Executive Non-departmental Public Body responsible to Defra) a strategic overview role for flood and coastal erosion risk management and required it to produce a strategy for flooding and coastal erosion in England (Environment Agency, 2011) which it did jointly with Defra. This strategy aims to manage risks in a sustainable way, so as to reduce the threat to people and property and deliver the greatest benefit to the environment, society and the economy. The strategic objective for the frame of reference at Pevensey is summarised as 'sustainable risk management'.

Defra has encouraged the development of a non-statutory strategic framework for coastal flood and erosion risk management based on Shoreline Management Plans (Defra, 2006). These provide large-scale assessments of the risks associated with coastal evolution and present a policy framework to address these risks to people and the developed, historic and natural environment in a sustainable manner. They operate at the level of a coastal sediment cell (Motyka and Brampton, 1993, Cooper and Pontee, 2006) or sub-cell.

The Shoreline Management Plan shoreline is split into Policy Units and a preferred management policy is developed for each unit. The shoreline management policies considered are those defined by Defra (2006), which constitute the range of available tactical objectives for the frame of reference:

- Hold the line: maintain or upgrade the level of protection provided by defences;

- Advance the line: build new defences seaward of the existing defence line;

- Managed realignment: allowing retreat of the shoreline, with management to control or limit movement;

- No active intervention: a decision not to invest in providing or maintaining defences.

At Pevensey the preferred tactical objective set in the shoreline management plan (Halcrow, 2006) is to hold the line in order to protect the low lying hinterland and shoreline settlements. The relationship of shoreline 
management plans and strategy studies to the planning and legal frameworks is outlined by Defra (2008, 2009).

\subsection{Decision-making process}

\subsubsection{Option selection}

The first element of the decision making process is to perform an analysis of the current state of the coast, including its behaviour, land use, functions and the different options that are proposed for implementing the chosen tactical objective. For example, the tactical objective 'hold the line' could have been implemented using hard defences, such as groynes, detached breakwaters or a seawall, by using a soft defence such as beach nourishment, or by a combination of both. In England and Wales this process is undertaken within a strategy study (Defra, 2009).

The preferred option for implementing the tactical objective at Pevensey (Hardacre and Chester, 2001) was by thickening the barrier beach to provide a 1 in 400 year standard of protection against breach, while removing many of the relict groynes and managing the barrier as an open beach. A secondary objective was to prevent loss of crest top properties, although the standard of protection varies with the location of the properties.

Once the means of implementing the tactical objective had been chosen, appropriate coastal state indicators were determined using studies of coastal erosion processes. The tactical objective of hold the line has two implicit physical characteristics, (i) position and (ii) standard of protection. These are associated with three Coastal State Indicators, known locally as Key Physical Features:

1. barrier position: the cross-shore position of the $+5 \mathrm{~m}$ contour at the front face of the defence;

2. beach width: the cross-shore distance between the $+5 \mathrm{~m}$ contour at both the front and rear of the defence; and

3. total beach volume: the measured cross-sectional area of the barrier integrated over the length of the barrier.

The $+5 \mathrm{~m}$ contours at front and rear were chosen to represent the cross-shore position of the shingle barrier as it was sufficiently high to represent the steep shingle rather than the underlying sand beach, without being above the measured elevation of the crest of the barrier beach at any point. Typical front and rear slopes of the barrier are known from the profile measurements so the minimum width between the front and rear $+5 \mathrm{~m}$ contours acts as a surrogate for the cross-sectional area of the barrier. If steeper slopes were to evolve generally, but beach widths remained within acceptable limits, this would be picked up by a reduction of the total beach volume.

The coastal state indicators used are measureable parameters that define the desired state of the coast in order to meet the chosen method of implementing the tactical objective. It follows that each potential option for implementing the tactical objective could have different coastal state indicators, so the relevant coastal state indicators can be determined only after the option for implementing the tactical objective has been chosen.

\subsubsection{Implementation}

The chosen option for delivering the tactical objective has been implemented on a month-by-month basis by Pevensey Coastal Defence since 2000 using a three-stage process: measurement, benchmarking and 
implementation (discussed in turn below). The Environment Agency then assesses the management of the beach every four months using the same three-stage process.

A series of 52 cross-shore profiles are measured at approximately $180 \mathrm{~m}$ centres by the Environment Agency every four months using GPS stake-out surveys. Moreover, Pevensey Coastal Defence conducts a full beach survey using a GPS receiver mounted on a quad bike each month at the lowest spring tide. Coordinates from the Pevensey Coastal Defence quad-bike surveys are loaded into a digital terrain model software package which creates a full 3D model of the beach. Volumes are extracted to mimic beach sections defined by each of the 52 Environment Agency profiles.

The benchmarking procedure consists of two stages: (i) derivation of coastal state indicators from regular measurements and (ii) comparison between the measured coastal state indicators and threshold values. Values of the coastal state indicators barrier position and beach width are extracted from each of the 52 profiles. Total beach volumes from the Environment Agency profiles are derived from sectional areas measured above the $0 \mathrm{~m}$ contour multiplied by each linear interval, which is typically around $180 \mathrm{~m}$. Total beach volumes from the Pevensey Coastal Defence surveys are extracted from the digital terrain model.

The observed coastal state indicators are then compared to their threshold values, which were determined by earlier studies and are set in Pevensey Coastal Defence's contract for managing the beach. The threshold value for the coastal state indicator, barrier position is that needed to maintain the beach width (given the more-or-less fixed position of the $+5 \mathrm{~m}$ contour on the rear face of the barrier). A penalty would be imposed on Pevensey Coastal Defence by the Environment Agency if the position of the front contour was eroded by more than $5 \mathrm{~m}$ from its threshold value, although sufficient time would be allowed for repair before a penalty would be levied.

The threshold value for the coastal state indicator beach width was determined from laboratory flume tests of erosion under severe conditions (HR Wallingford, 1995) plus a $5 \mathrm{~m}$ minimum beach width. An ideal beach profile was derived using natural beach slopes to the front and rear of the $+5 \mathrm{~m}$ contour, 1:4 slopes between $+5 \mathrm{~m}$ and $+6 \mathrm{~m}$ and the threshold value of beach width at $+5 \mathrm{~m}$. The threshold value for total beach volume is found by integrating the ideal cross-sectional areas at each of the 52 profiles. The total beach volume is only allowed to fall by $40,000 \mathrm{~m}^{3}$ from its target total volume before a penalty would be imposed on Pevensey Coastal Defence by the Environment Agency, although sufficient time would be allowed for repair before a penalty would be levied. Although it is not clear where the $40,000 \mathrm{~m}^{3}$ limit came from, it is likely to be an estimate of the measurement error added to the loss of shingle from the profiles due to beach draw-down during a storm that may be recovered through onshore transport afterwards.

Variations between the measured and target values of the three coastal state indicators are used to identify the location and extent of works that may be required to return the indicators to their threshold values. The choice of intervention is made by an expert manager, who takes into account the likely timescale of activities. For example, since 2004 there has been one maintenance recharge and up to three periods of bypassing at Sovereign Harbour each year between August and March. The coastal manager must therefore ensure that these operations provide sufficient sediment to the beach to account for all losses from the beach until the next autumn's beach nourishment can occur, without allowing the beach volume to drop by more than $40,000 \mathrm{~m}^{3}$ (about $2 \%$ ) from its target value.

During the winter recycling is undertaken to reinforce depleted areas using sediment from areas that are accreting. This generally involves the movement of shingle in dump trucks along the beach from east to west. Some re-profiling of beach also occurs, which involves pushing shingle back towards the barrier crest to maintain the target width at the top of the barrier. 
The probability of the total beach volume falling more than $2 \%$ below its target volume, or of the beach width being less than its target volume at any of the 52 specified profiles could be reduced by adding a large volume of sediment to the beach, so that each target value of the CSI was comfortably exceeded. This would involve paying a large bill up front, the cost of which may take years to re-coup, given the agreed payment schedule in the beach management contract. Experience also indicates that putting double the usual amount of recharge on the beach will not mean it will last twice as long. Excessive nourishment only serves to push the beach out of equilibrium, which increases the drift rate and the rate of sediment loss from the system. Thus in the end the cost of a large, precautionary nourishment would most likely not be recouped at all. It is in Pevensey Coastal Defence's interest to have sufficient, but not excessive volume of sediment in the beach.

Evaluation of the effectiveness of each intervention consists of using the benchmarking procedure after the following monthly survey. If the intervention was planned and executed successfully the measured values of all three coastal state indicators would be above their target values.

\subsection{Evaluation against objectives}

At Pevensey the tactical objective is reviewed at each new round of the Shoreline Management Plan (SMP) process, which occurs about every five to ten years. This review will be influenced by the effectiveness of the existing management, in terms of benefits delivered and costs incurred.

If the tactical objective were to change in a new SMP, or there was a suggestion that another method of implementation would be better, a new strategy study would have to be undertaken to determine how the tactical objective should be met (Figure 8). This would potentially require a new set of coastal state indicators within the decision-making process. The details of a benchmarking procedure would then be chosen and implemented by a revised scheme. However, the contract for managing the beach is based on a tactical objective of 'hold the line' and any change in that objective would require a re-negotiation of the contract.

Moreover, the entire SMP process is reviewed after each round of SMPs and resulting rules for production of SMPs may be amended (Defra, 2006). The strategic objective is ultimately set by government as part of the political process. For example, the Flood and Water Management Act (HMSO, 2010) required the Environment Agency to produce a national strategy for flood and coastal erosion risk management (Environment Agency, 2011).

\subsection{Differences from generic frame of reference}

Figure 8 has been modified from the generic frame of reference (van Koningsveld and Mulder, 2004, Marchand et al., 2011). Both start with strategic and tactical objectives and have a four-stage management process. In the generic frame of reference the four stages are

1. Quantitative state concept: a means of quantifying the problem in hand. Coastal state indicators are chosen at this stage of the process.

2. Benchmarking process: a means of assessing whether or not action is required. Coastal state indicators are compared to a threshold value at this stage.

3. Intervention procedure: A detailed definition of what action is required if the benchmark values are exceeded.

4. Evaluation procedure: Impact assessment of the action taken. 
Option selection has replaced the quantitative state concept as the first stage of the decision-making process in Figure 8. The present approach explicitly includes the selection of an option for implementing the tactical objective, the derivation or selection of appropriate coastal state indicators and the selection of the threshold values for the coastal state indicators within option selection as these are all carried out within a Strategy Study. However, option selection and quantitative state concept both involve an analysis of the current state of the coast and the selection of appropriate coastal state indicators, so the change is more a matter of emphasis (by highlighting that there is more than one way of implementing the tactical objective) than a change in the process.

Figure 8 and the generic frame of reference then feature regular benchmarking by comparing measured coastal state indicators to their threshold values and both have a specific intervention process, should a threshold be crossed. Figure 8 shows a closed loop of measurement, benchmarking and intervention, which is informed by the setting of thresholds for the coastal state indicators, within a dashed box to indicate that this is carried out by Pevensey Coastal Defence as part of their contract. There is also a closed loop with the same elements within the generic frame of reference.

The evaluation procedure is slightly different in Figure 8 compared to the generic frame of reference. The long-term success of the management process is undertaken, at a broad scale, when the Shoreline Management Plan is revised. If the tactical objective is changed, or it is felt that a different option may be better for implementing it, the management process would be reviewed in more detail within a new Strategy Study. There is no corresponding feedback from the evaluation process to the quantitative state concepts in the generic frame of reference.

There is also no direct feedback from the evaluation to the strategic objective in Figure 8 , as there is in the generic frame of reference. The feedback to the strategic objective (which is set by the government) comes from a review of an entire round of Shoreline Management Plans covering the entire coastline of England and Wales, so is given as feedback from the tactical objective (set in Shoreline Management plans) to the strategic objective. In both representations there is a process for reviewing the success of the beach management process against the tactical objectives and the strategic objectives. The application to Pevensey also includes a periodic review of whether the range of tactical objectives that may be set is appropriate.

The differences between the application of the frame of reference to Pevensey and the generic frame of reference are seen to come from the details of the application, rather than changes in the principles of the application. In particular, more emphasis is given at Pevensey to the selection of an option for implementing the tactical objective.

\section{Suitability of the key Eurosion concepts}

The key concepts for the management of coastal erosion proposed by the Eurosion project (European Commission, 2004) are coastal resilience, strategic sediment reservoirs, favourable sediment status and the coastal sediment cell. Their definitions, adaptation to Pevensey and suitability for use at Pevensey are described in Sections 4.1 to 4.4 respectively.

\subsection{Coastal resilience}

The Eurosion project (European Commission, 2004) recommended that erosion is combated through the promotion of coastal resilience, defined as "the inherent ability of the coast to accommodate changes 
induced by sea level rise, extreme events and occasional human impacts, whilst maintaining the functions fulfilled by the coastal system in the longer term."

It is arguable that the occasional construction of a structure, such as a groyne at Pevensey, leads to a longterm human impact on the beach. Moreover, adaptive management requires there to be regular management intervention, not just occasional ones. (Adaptive management may be seen as a response to a lack of natural resilience by artificially intervening to promote resilience.) The Eurosion definition of coastal resilience only refers to occasional human impacts, so it is not clear that it applies to situations with structures, or that are adaptively managed. It might be better if the word 'occasional' was dropped from the definition.

However, the two key factors identified by Eurosion for determining whether coastal systems are resilient or not were sediment supply and space for coastal processes to operate, which can be assessed for situations with structures or with adaptive beach management.

At Pevensey there is a chronic and persistent loss of sediment from the shingle barrier, which is compensated for by nourishment. Moreover the tactical objective of 'hold the line' places a severe constraint on the space for coastal processes to operate, which must be seawards of the held line. This is achieved by providing a limited beach width that is sufficient to accommodate changes in morphology caused by sediment transport between bypassing, nourishment and recycling operations. The managed-adaptive approach provides a shingle barrier that is resilient over timescales of months.

This approach is in line with recommendation 27 of the Pitt review into the 2007 floods (Pitt, 2008): 'Defra, the Environment Agency and Natural England should work with partners to establish a programme through ... Shoreline Management Plans to achieve greater working with natural processes'. The Flood and Water Management Act (HMSO, 2010) and the subsequent flood and coastal erosion strategy (Environment Agency, 2011) also promote the integrated management of flooding and coastal erosion that 'understands and works with natural processes' so all three promote coastal management practices that allows space for natural processes to occur and hence the concept of coastal resilience.

\subsection{Strategic sediment reservoirs}

Eurosion (European Commission. 2004) defined strategic sediment reservoirs as "supplies of sediment of 'appropriate' characteristics that are available for replenishment of the coastal zone, either temporarily (to compensate for losses due to extreme storms) or in the long term (at least 100 years). They can be identified offshore, in the coastal zone (both above and below low water) and in the hinterland."

Gravel and shingle for beach nourishment are selected to have size characteristics similar to the material that form the beach, as the existing material will be in a form of dynamic equilibrium with the prevailing wave and water level conditions. This limits the range of sources that can be considered appropriate. Intra-annual strategic sediment reservoirs are found in Pevensey shingle barrier itself, where local areas of accretion are detected by the surveys and can be re-cycled along the beach.

The use of marine aggregates for beach nourishment has environmental and economic advantages over the use of land-won aggregates, as large volumes can be sourced relatively close to the beach and pumped directly onto a beach (Figure 3). Each nourishment of the Pevensey beach in the last 10 years has used shingle from either Hastings Bank or Owers Bank offshore dredging areas (Figure 1), which act as the defacto strategic sediment reservoirs. 
The volume of workable gravel (greater than $5 \mathrm{~mm}$ ) offshore from southern England was estimated by Humphries et al. (1996) to be about $2.25 \times 10^{8} \mathrm{~m}^{3}$ which amounts to only about 30 years supply at present day extraction rates (Bingham and Russell, 2008). Continuation of the supply of offshore sand and gravel will occur through the award of further extraction licences and through improvements in techniques for locating and extracting offshore gravel. Some new extraction licenses now allow extra extraction of sand and gravel for use in beach recharge schemes, particularly if the material is not suitable for construction (Rogers et al, 2010, Chapter 14).

However, the concept of the strategic sediment reservoir is not used in the UK and has no official recognition. Those wanting dredged material for beach nourishment have to compete with a host of other potential users of aggregates for the annual allocation. Approximately $79 \%$ of marine sand and gravel in the UK is sold as concrete aggregate and in London and the South-East this figure is 89\% (Highley et al., 2007). In this situation, the long-term planning of sediment supply, perhaps including the prospecting and licensing of dedicated dredging areas for beach recharge, could be beneficial.

\subsection{Favourable sediment status}

Eurosion (European Commission, 2004) defined favourable sediment status as 'the situation where the availability of coastal sediments supports the objective of promoting coastal resilience in general and of preserving dynamic coastlines in particular.' The barrier beach at Pevensey can be said to have achieved favourable sediment status when all coastal state indicators have been exceeded and there is a supply of suitable shingle available for beach nourishment. The concept of 'favourable sediment status' is therefore a useful way of summarising the status of the beach at Pevensey as it includes both processes (through coastal state indicators) and availability of supply.

However, as the strategic sediment reservoir is not reserved for beach nourishment, favourable sediment status can be retained on an annual basis only, when a supply of shingle has been secured. Pevensey Coastal Defence has accepted the risk of not being able to maintain favourable sediment status up until 2025. This risk was considered acceptable as other (more costly) sources of sediment are available, techniques for mapping and extracting marine aggregates are improving (which may lead to new license areas becoming available) and Pevensey Coastal Defence's main shareholder is a dredging contractor.

\subsection{Coastal sediment cell}

Eurosion (European Commission, 2004) defined Coastal sediment cell as a 'coastal compartment that contains a complete cycle of sedimentation including sources, transport paths, and sinks. The cell boundaries delineate the geographical area within which the budget of sediment is determined, providing the framework for the quantitative analysis of coastal erosion and accretion. In this respect, coastal sediment cells constitute the most appropriate units for achieving the objective of favourable sediment status and hence coastal resilience.'

Motyka and Brampton (1993) mapped eleven major sediment cells for the littoral drift of beach sand in England and Wales. Four of the sediment cell boundaries were at estuaries while eight were at major headlands that acted as littoral drift divides. Each cell was subdivided into a number of sub-cells, between which there was limited transport of beach sediment, so that the beach behaviour on one side of the sub-cell boundary was judged to be only partially dependent on beach management on the other side. Beachy Head was identified as the western end of coastal sub-cell 4c, as little beach material is transported round it. This sub-cell includes Pevensey Bay and extends east to South Foreland (Figure 1). 
The cells and sub-cells were subsequently used to define the boundaries of the first round of Shoreline Management Plans. Cooper and Pontee (2006) reviewed and revised the sediment cell boundaries for a second round of Shoreline Management Plans to recognise the importance of cohesive sediment transport, the influence of estuaries on coasts, geology and on-offshore exchanges. Some cell boundaries were moved, particularly at estuaries, but not the boundaries of sub-cell 4c.

One limitation of the concept of the sediment cell is that it focuses attention on the appropriate spatial scale for the consideration of wave driven littoral sediment transport only. Recently in the UK a behavioural systems based approach (Defra, 2002) and a methodology for coastal systems mapping (Whitehouse et al, 2009) have been developed that promote the consideration of processes at a range of different scales and which could form the basis for a coastal sediment management system that looks beyond the sediment cell.

The Eurosion definition also makes no explicit reference to timescale, although the spatial extent required to encompass a 'complete cycle of sedimentation including sources, transport paths, and sinks' will vary with the timescale considered. The implicit timescale used in the UK is one of centuries to millennia. Hence, for example, the chalk cliffs of Beachy Head form part of the sediment source, even though the chalk was formed in an ancient sediment sink and in another few million years they may have eroded far enough not to form a sub-cell boundary.

Sub-cell boundaries are crossed by a normally small, quantifiable (or insignificant) volume of beach sediment. Although they do not correspond fully to the Eurosion definition of a sediment cell, they provide a shorter domain to be managed, which crosses fewer administrative boundaries and may allow more local representation during the consultation process for a Shoreline Management Plan. Moreover, sediment budgets can still be calculated as the transport across the boundary can normally be estimated, so a quantitative analysis of erosion and accretion can still be undertaken.

The risk of coastal erosion and flooding varies within a sub-cell, so different tactical objectives may be implemented along different stretches of coastline. Sub-cells are split into policy units - each with its own tactical objective - to reflect the varying risks along the coastline. The shingle barrier beach at Pevensey and Sovereign Harbour Marina covers two policy units. To the east and the west, the backshore rises above the extreme water level, so there is no risk of coastal flooding and the beach management policy changes. Policy units are not small-scale sediment cells, as they do not contain a complete cycle of sedimentation, although a sediment budget can be calculated for each.

The concept of sediment cells (and sub-cells) is used as the first step in dividing the coastline for coastal management. Their introduction was a key step towards managing the coast in a holistic manner that respects physical processes, rather than political boundaries. Their use is important, but not sufficient, for coastal management in England and Wales.

\section{Conclusions}

The shingle barrier beach at Pevensey Bay in East Sussex, UK, protects over 10,000 properties, trunk roads, a mainline railway, caravan parks and land with high conservation and agricultural value from flooding and erosion. On average the barrier beach looses about $20,000 \mathrm{~m}^{3}$ of single per year. A managed adaptive approach has been developed to implement the preferred approach to delivering the coastal management policy of 'hold the line'. This involves periodic capital recharge (beach nourishment) annual maintenance recharge, bypassing round a harbour, recycling along the beach and re-profiling of the beach. 
This managed-adaptive approach can be implemented using the frame of reference approach as the key physical features used are coastal state indicators. However, this paper shows that the first stage of the decision-making process should incorporate the selection of an option for implementing the tactical objective. The choice of option will influence the choice of coastal state indicators and the threshold values which should prompt intervention.

The large-scale management of the coastline of England and Wales has been organised on the basis of coastal sediment cells and sub-cells since the introduction of Shoreline Management Plans over 10 years ago. Reviews of first round SMPs have shown this to be an important but not sufficient approach as it is formulated around the wave-driven littoral transport of sand and did not take account of other important factors such as geological controls and other sediment sizes. Strategy Studies cover smaller areas in more detail, with the extent of these areas governed by an understanding of physical processes and the main risks, rather than administrative boundaries.

The Eurosion definition of coastal resilience implies a long-term natural ability to accommodate change without loss of function(s). In many cases, such as Pevensey, this is an ideal that can be promoted only through the long-term nourishment of the beach from an external (here offshore) source. Elements of the concept are already being incorporated into policy however with recognition of the need to understand and work with natural processes.

The beach is managed so that it retains favourable sediment status throughout. This can only be achieved by the addition of suitable sediment from the strategic sediment reservoir. However the concepts are not used in the UK so the strategic sediment reservoir is not reserved for beach nourishment. Nor is the need for suitable size of aggregate recognised in the new provisions for marine spatial planning in the UK. This is an area where the promotion of the Eurosion concept of a strategic sediment reservoir could be useful in assuring the provision of beach nourishment material.

The concept of favourable sediment status is a potentially useful way of summarising the status of the beach at Pevensey that integrates both processes (through coastal state indicators) and availability of supply. However, its use is essentially restricted to situations where the beach plays an important role. In many situations in the UK a resistant (as opposed to resilient) strategy is adopted that relies on hard defences or rock cliffs. Favourable sediment status would not be met in many UK locations where a perfectly adequate standard of protection is maintained by the use of hard structures or the presence of a cliff and rock shore platform.

\section{Acknowledgements}

The work described in this paper was supported by the European Community's Sixth Framework Programme through the grant to the budget of the Specific Targeted Research Project CONSCIENCE, Contract No. 044122 (SSPI). Additional support was received from HR Wallingford and Pevensey Coastal Defence Limited. Wave data was supplied by the Channel Coastal Observatory, which is the data management centre for the Southeast Regional Coastal Monitoring Programme, funded by Defra, in partnership with the Maritime Local Authorities and the Environment Agency Southeast Region.

\section{References}

Bingham, J., Russell, M., 2008. Marine Aggregates Reserves: The Crown Estates Licenses as at 1 September 2008. Crown Estate report, pp6. 
Cooper, N.J., Pontee, N.I., 2006. Appraisal and evolution of the littoral 'sediment cell' concept in applied coastal management: experiences from England and Wales. Ocean and Coastal Management 49: 498 510.

Defra, 2002. Futurecoast. CD-ROM.

Defra, 2006. Shoreline management plan guidance (2 volumes). Department for Environment, Food and Rural Affairs publication PB11726. Internet: http://www.defra.gov.uk/publications/ (page accessed 13 June 2011).

Defra, 2008. A strategy for promoting an integrated approach to the management of coastal areas in England. Department for Environment, Food and Rural Affairs publication PB13199.

Defra, 2009. Appraisal of flood and coastal erosion risk management, a Defra policy statement. Department of Environment, Food and Rural Affairs publication PB13278. Internet: http://www.defra.gov.uk/publications/ (page accessed 13 June 2011).

Environment Agency, 2011. The national flood and coastal erosion risk management strategy for England. Available from www.official-documents.gov.uk.

European Commission, 2004. Living with coastal erosion in Europe - sediment and space for sustainability. Luxembourg: Office for Official Publications of the European Communities. pp. 40, ISBN 92-894-8496-3.

Halcrow, 2006. South Foreland to Beachy Head Shoreline Management Plan.

Hardacre, G. and Chester, F., 2001. Pevensey Bay Sea Defences PPP, 'the contractors perspective'. Proceedings of the $36^{\text {th }}$ DEFRA Conference of River and Coastal Engineers. Keel University. 07.5.107.5.7.

Highley, D.E., Hetherington, L.E., Brown, T.J., Harrison, D.J., Jenkins, G.O., 2007. The strategic importance of the marine aggregate industry to the UK, British Geological Survey Research Report OR/07/019. ISBN 9780852726082.

HMSO, 2010. Flood and Water Management Act. Internet: http://www.legislation.gov.uk/ (page accessed 16 June 2011).

HR Wallingford, 1995. Langley Point to Cooden Sea Defences, physical model studies. Report EX 3241. pp160.

Humphreys, B., Coates, T., Watkiss, M., Harrison, D., 1996. Beach recharge materials - demand and resources. CIRIA Report R154, pp 176. ISBN 0860174395

JBA, 2004. Extreme sea level analysis - Kent, Sussex, Hampshire and Isle of Wight. Updated summary report for Environment Agency Southern Region. Pp27.

Marchand, M., Sànchez-Arcilla, A., Ferreira, M., Gault, J., Jiménez, J., Markovic, M., Mulder, J., van Rijn, L., Stanica, A., Sulisz, W., Sutherland, J., 2011. Concepts and science for coastal erosion management - an introduction to the CONSCIENCE framework. Ocean and Coastal Management, this volume.

Motyka, J.M., Brampton, A.H., 1993. Coastal Management: mapping of littoral cells. HR Wallingford Report SR328.

Pitt, Sir M., 2008. Learning lessons from the 2007 floods. London, The Cabinet Office.

Rogers, J., Hamer, B., Brampton, A., Challenor, S., Glennerster, M., Brenton, P. Bradbury, A. 2010. Beach Management Manual (second edition). CIRIA C685. ISBN: 978-0-86017-682-4-3. 
Stripling, S., Bradbury, A.P., Cope, S.N., Brampton, A.H. 2008. Understanding Barrier Beaches. Joint Defra/EA Flood and Coastal Erosion Risk Management R\&D Programme, R\&D Technical Report FD1925/TR. Internet: available from http://sciencesearch.defra.gov.uk

van Koningsveld, M., Mulder, J.P.M., 2004. Sustainable coastal policy developments in the Netherlands. A systematic approach revealed. Journal of Coastal Research, 20(2), 375-385.

Whitehouse, R., Balson, P., Beech, N., Brampton, A., Blott, S., Burningham, H., Cooper, N., French, J., Guthrie, G., Hanson, S., Nicholls, R., Pearson, S., Pye, K., Rossington, K., Sutherland, J., Walkden, M., 2009. Characterisation and prediction of large scale long-term change of coastal geomorphological behaviours: final science report. Science Report SC060074/SR1, Environment Agency, Bristol. ISBN 978-184911-090-7 pp 276. 
Table 1: Marginal extreme wave heights from wave buoy and water levels from JBA (2004)

\begin{tabular}{|l|r|r|}
\hline Return period (years) & Wave height $(\mathrm{m})$ & $\begin{array}{r}\text { Water level } \\
(\mathrm{mOD})\end{array}$ \\
\hline 1 & 3.67 & 4.3 \\
\hline 10 & 4.57 & 4.6 \\
\hline 100 & 5.34 & 4.9 \\
\hline
\end{tabular}




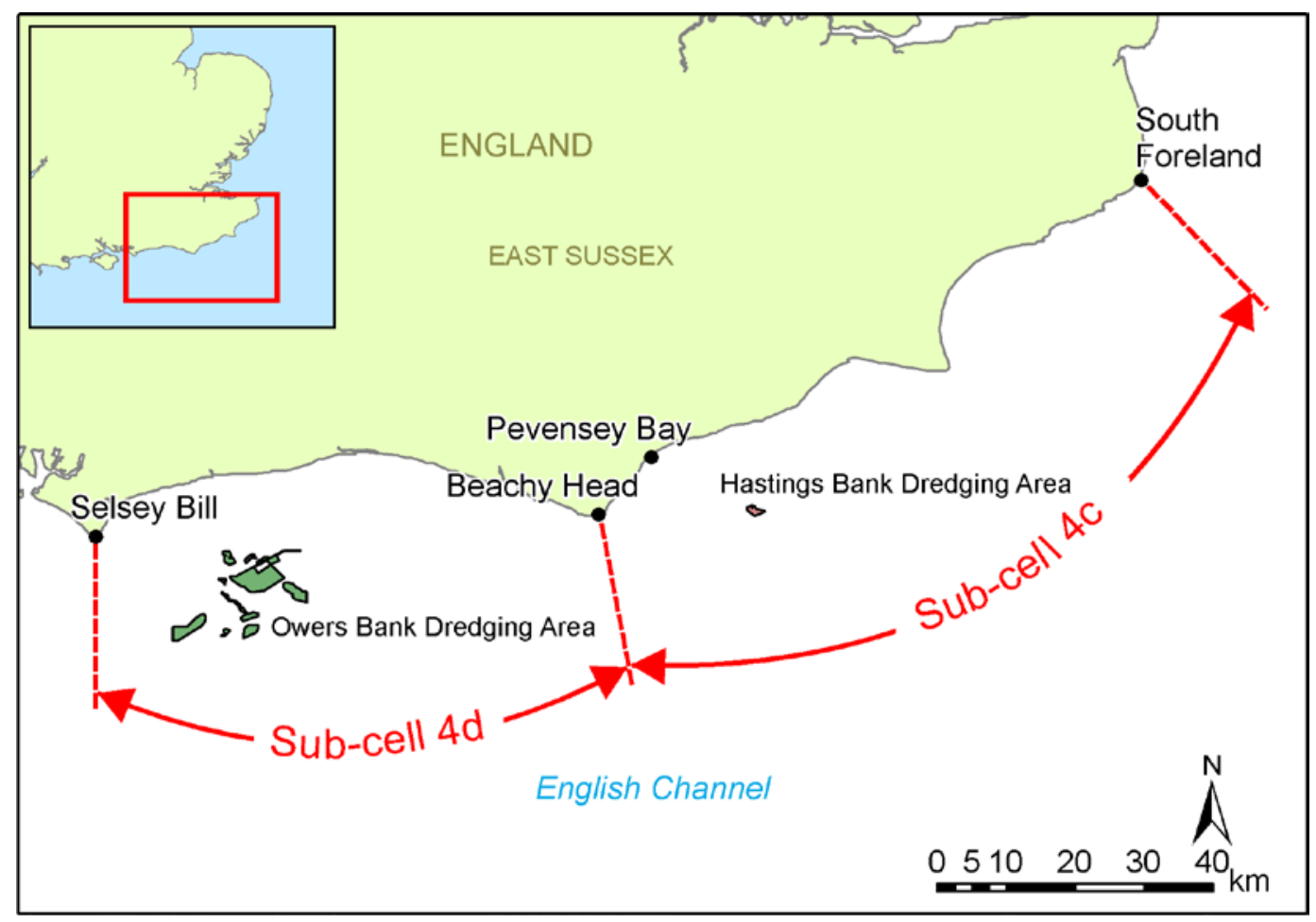

Figure 1: Sub-cell boundaries, aggregate dredging areas and main locations

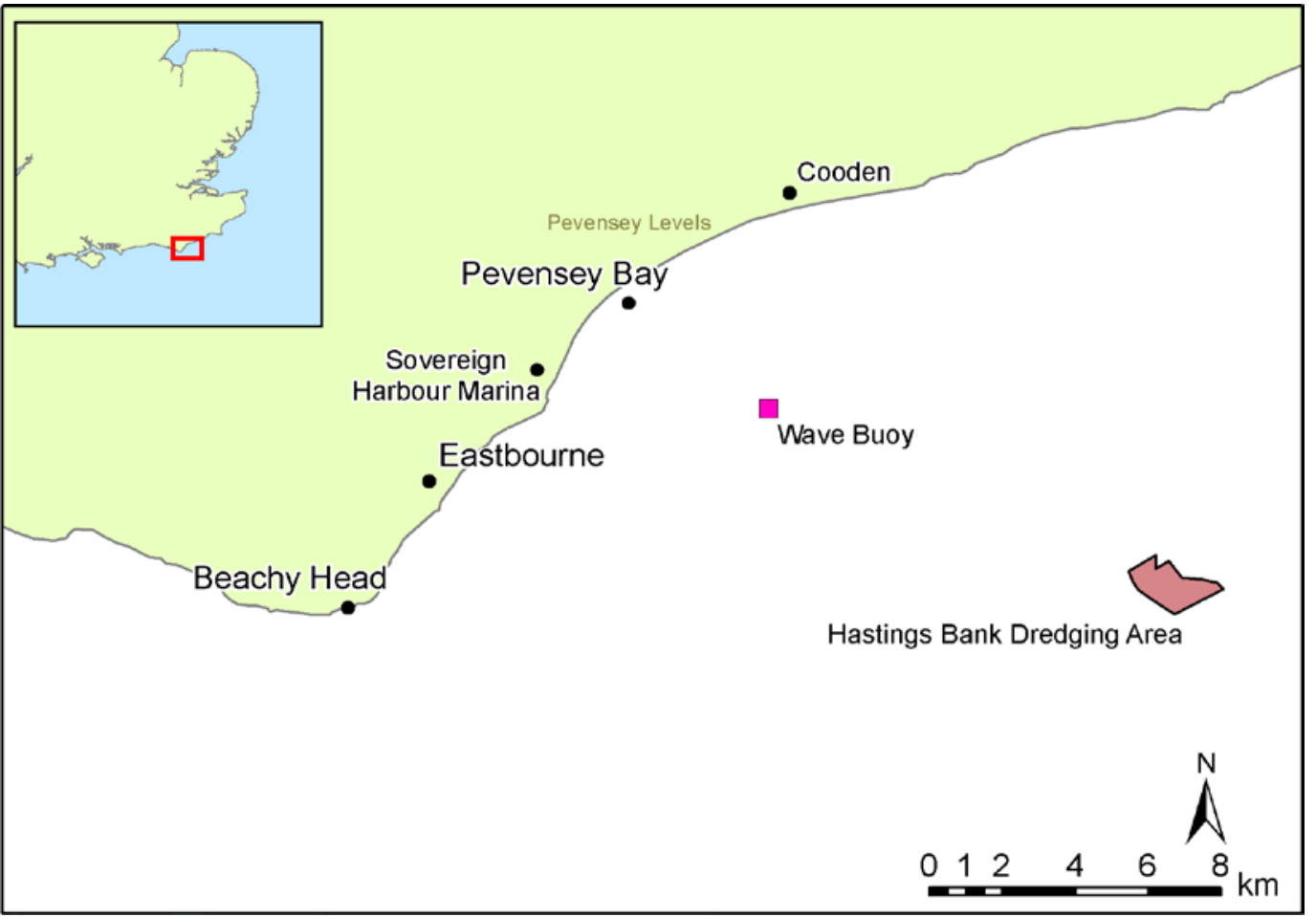

Figure 2: Local map of Pevensey Bay 


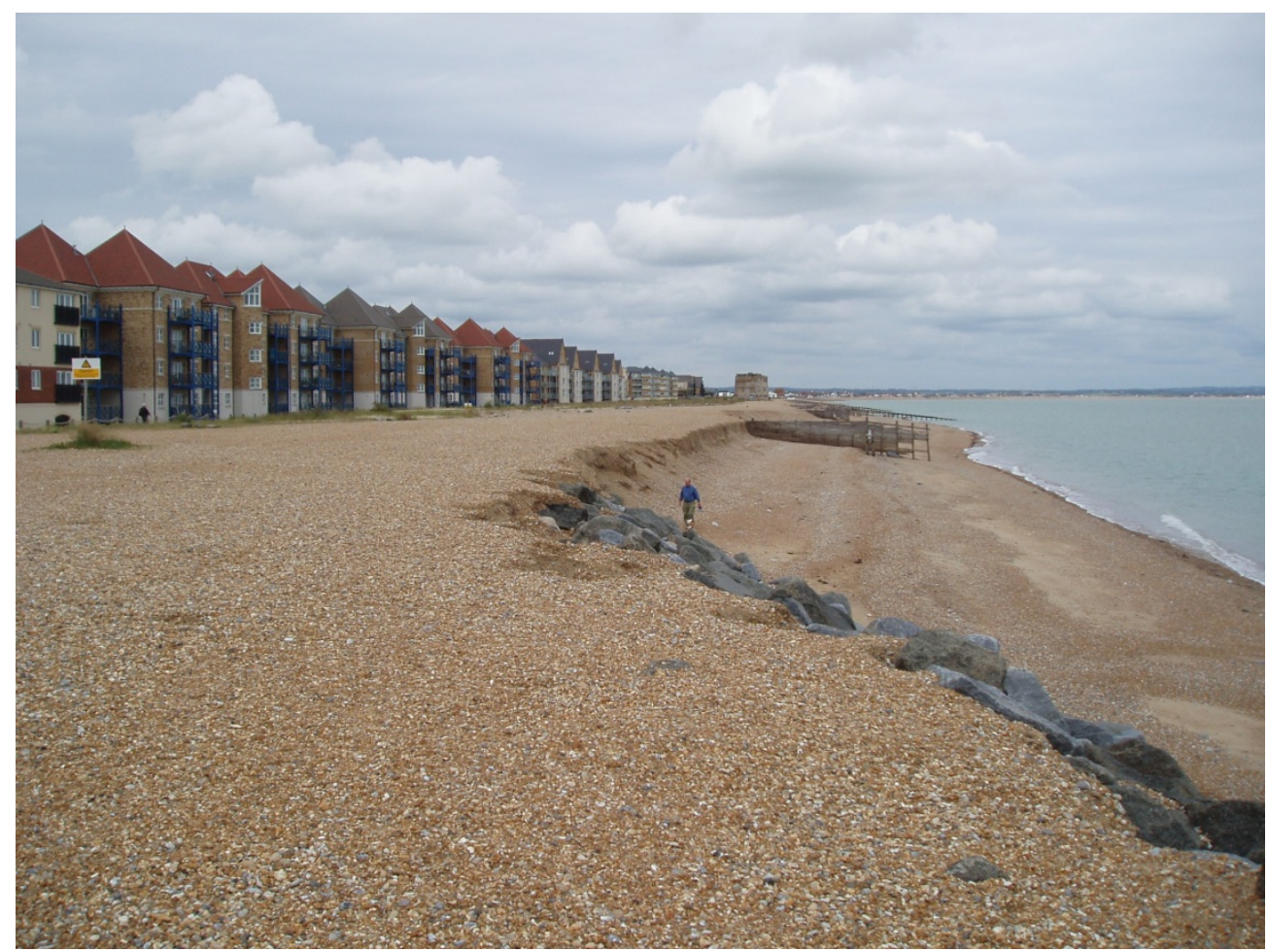

Figure 3: Erosion north of Sovereign Harbour in 2008

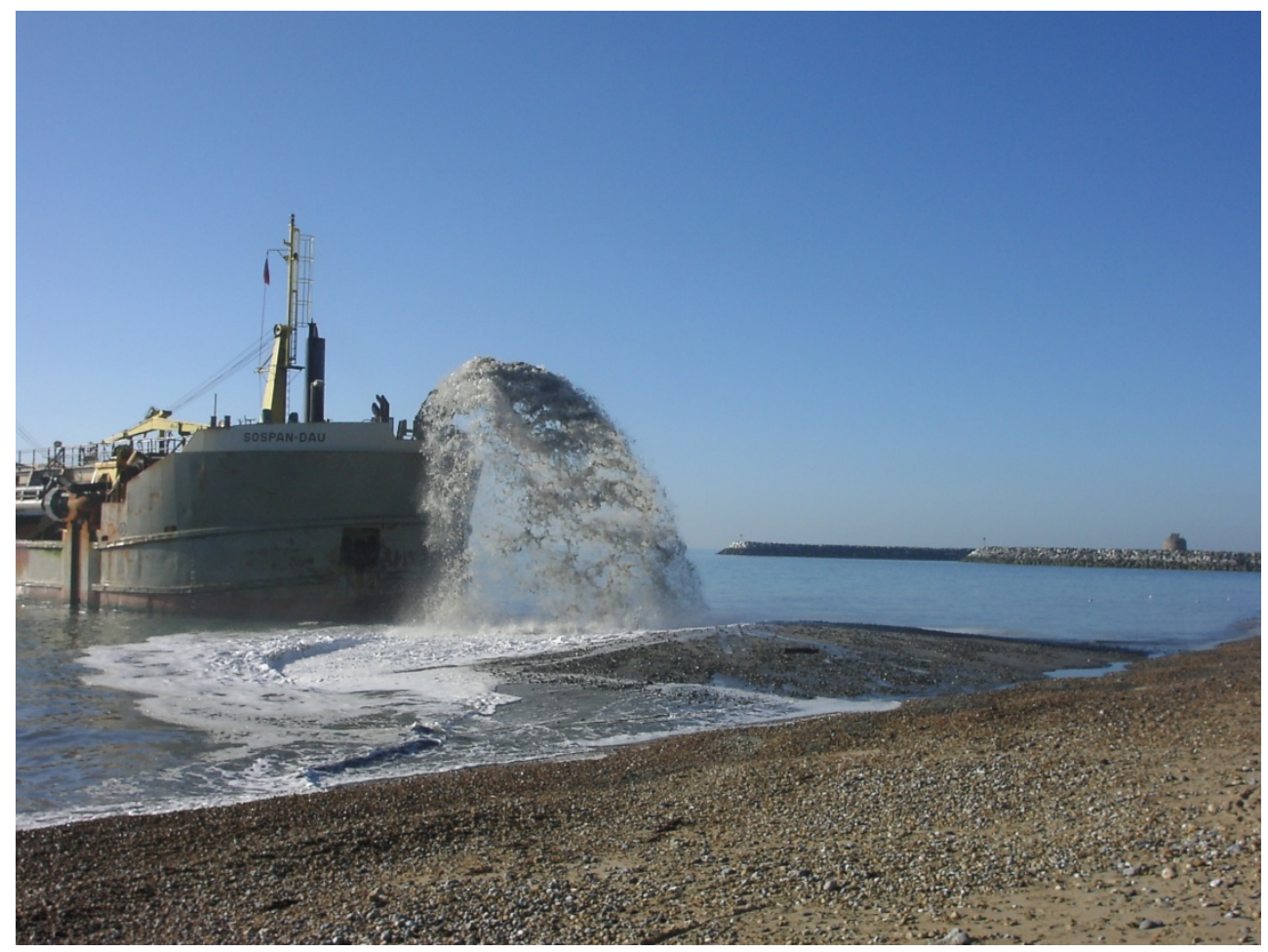

Figure 4: Beach recharge north of Sovereign Harbour in 2005 


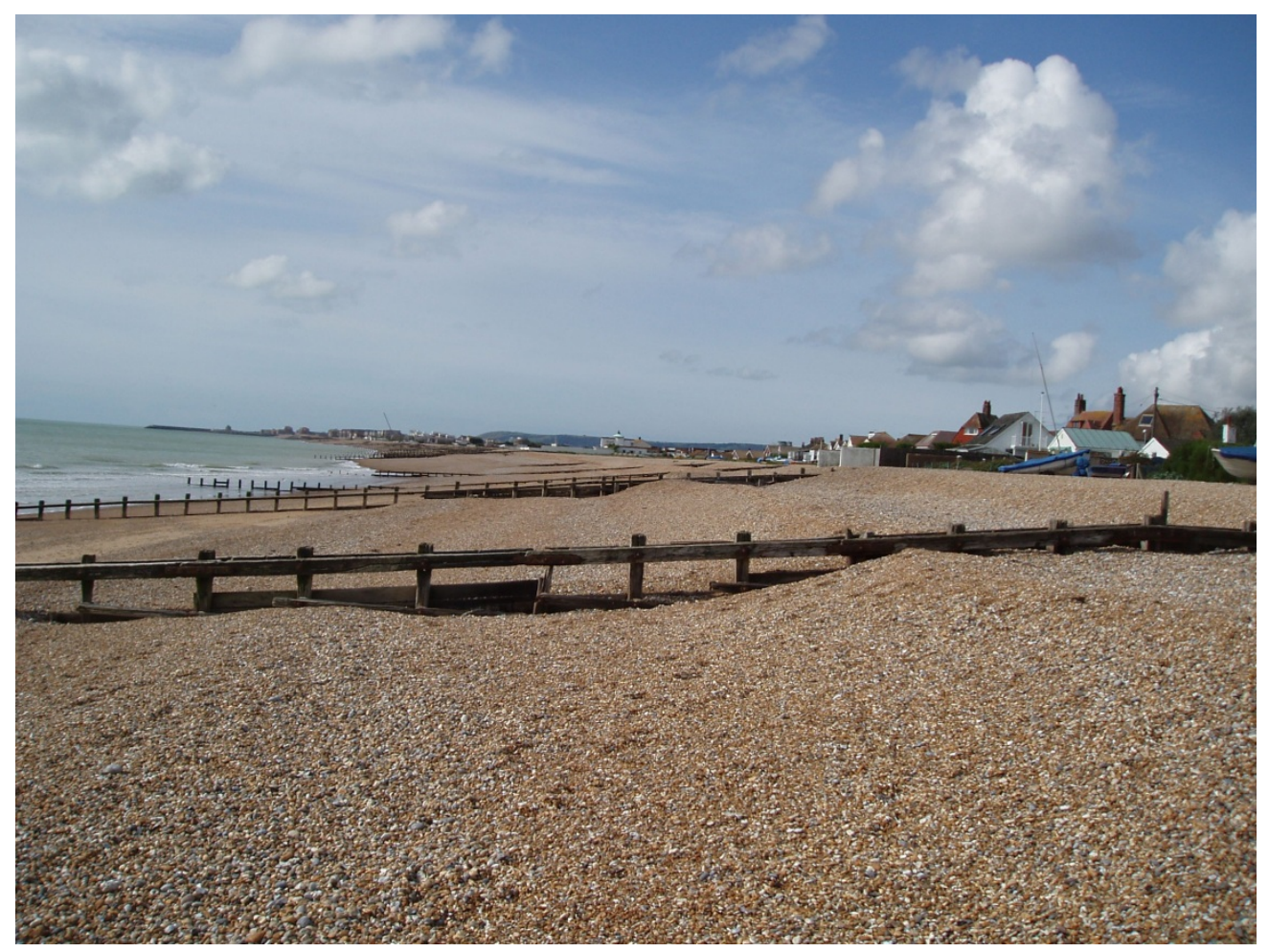

Figure 5: Old groynes at Pevensey

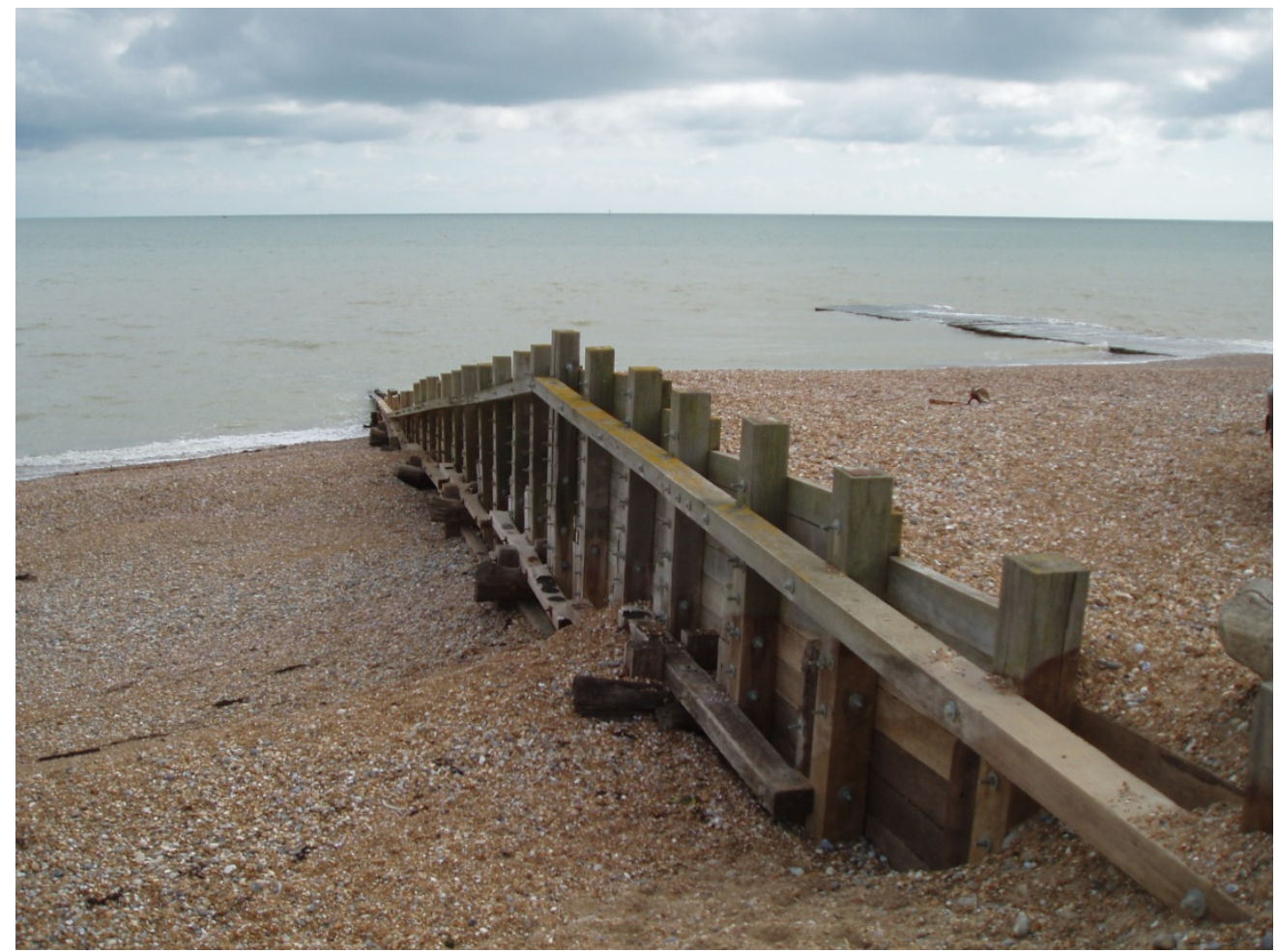

Figure 6: New groyne between Pevensey and Cooden 


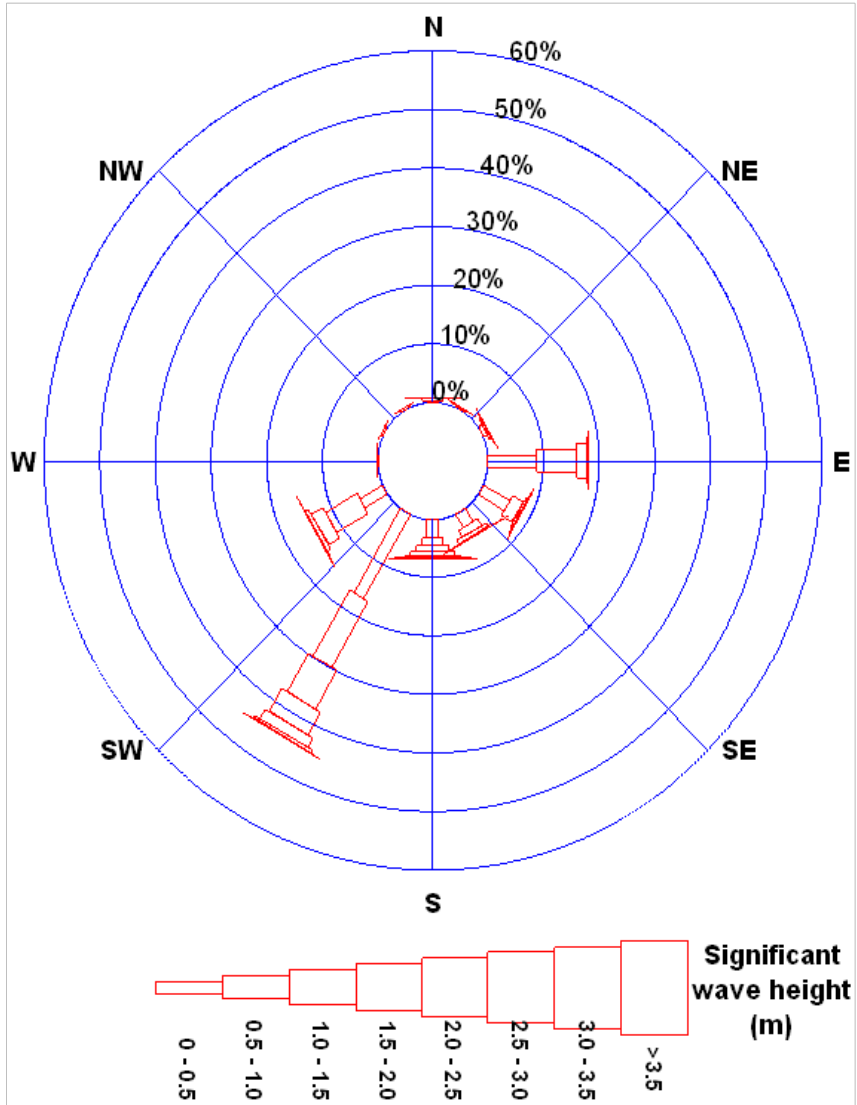

Figure 7: Wave rose from directional buoy in Pevensey Bay 


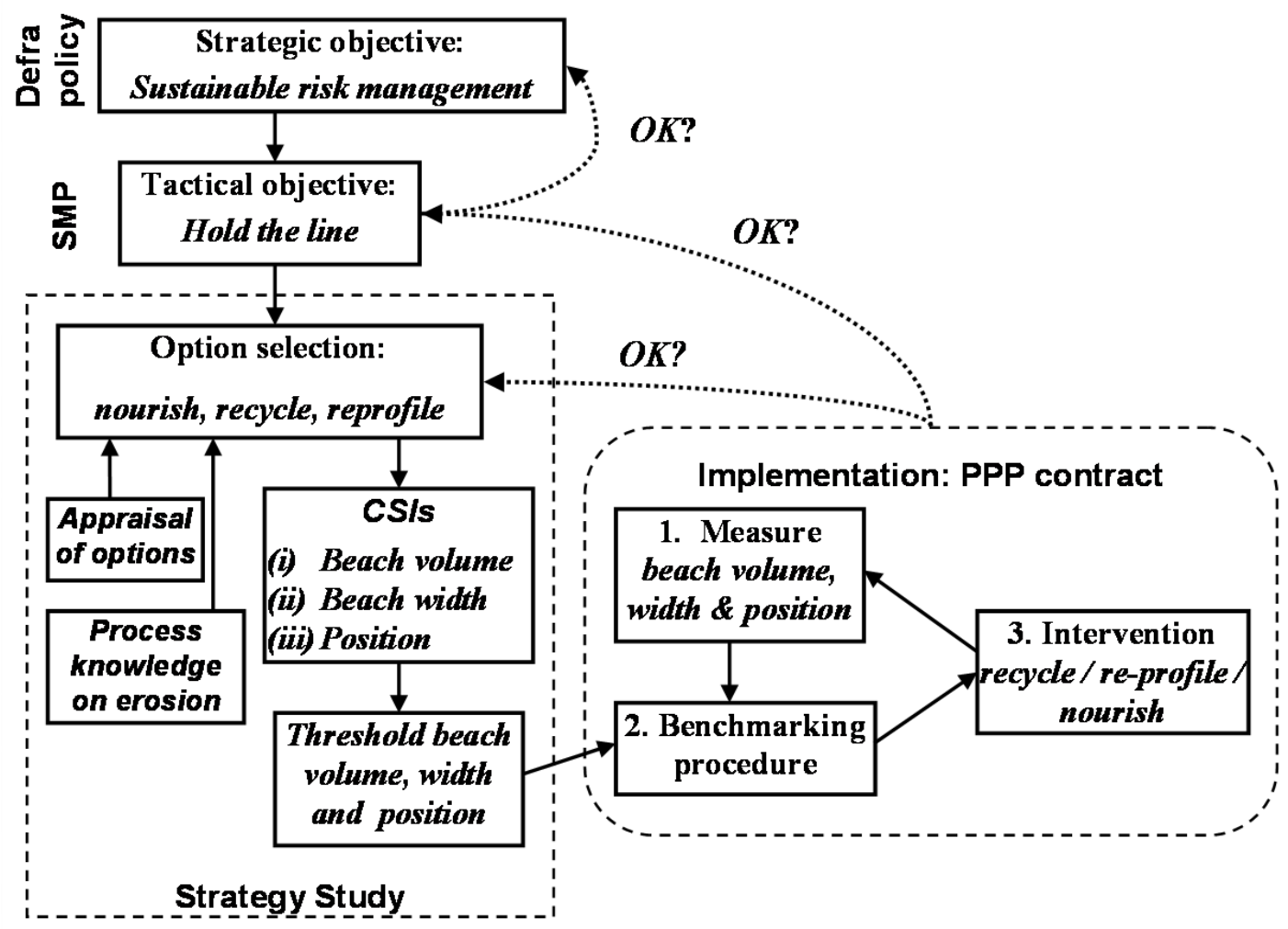

Figure 8: Application of the Frame of Reference approach to Pevensey 